\title{
Effective Communication-Based Teaching Skill for Early Childhood Education Students
}

\author{
Yuliani Nurani ${ }^{1}$, Sofia Hartati ${ }^{1}$, Ade Dwi Utami ${ }^{1,2}$, Hapidin $^{1}$ \& Niken Pratiwi ${ }^{1}$ \\ ${ }^{1}$ Early Childhood Education Departement, Faculty of Education, Universitas Negeri Jakarta, Jl. Rawamangun Muka, \\ Jakarta Timur, 13220, Indonesia \\ ${ }^{2}$ Early Childhood Education Departement, Monash University, 12345, Australia \\ Correspondence: Yuliani Nurani, Early Childhood Education Departement, Faculty of Education, Universitas Negeri \\ Jakarta, Jl. Rawamangun Muka, Jakarta Timur, 13220, Indonesia. E-mail: yuliani.nurani@unj.ac.id
}

Received: November 9, 2019

Accepted: December 4, 2019

Online Published: December 5, 2019

doi:10.5430/ijhe.v9n1p153

URL: https://doi.org/10.5430/ijhe.v9n1p153

\begin{abstract}
The research aims to develop a series of effective communication-based teaching skills for early childhood education teachers that develop in accordance with the Indonesian National Curriculum framework used recently in Department of Early Childhood Education, Faculty of Education, State University Jakarta. Research will be conducted in two years using research and development methods. The literature review has been conducted on effective communication and teaching skills for the first year and a series of teaching skill indicators. Data gathered from early childhood education teachers in Jakarta are related to the theory and practice of teaching skills with observation, interviews and performance tests. The results of the study are indicators for Early Childhood Education (PAUD) teacher teaching skills. On the other hand, drafts of effective communication practices are conducted to be applied in teacher teaching skills. These two concepts will be used to develop a model of effective communication based teaching skills for teachers of early childhood. The result can be consideration of educational institutions educators, researchers and governments in developing training models to improve teacher teaching skills.
\end{abstract}

Keywords: teacher, teaching skill, effective communication, early childhood education

\section{Introduction}

An education process through learning is important in encouraging children's learning. This learning activity provides active interactions between teachers and children. In this case, the teacher plays an important role in children's learning. Hence the success of their education requires the professionalism of teachers. Previous studies have explained that teacher performance and characteristics contribute to students ' positive achievements significantly (Wenglinsky, 2002)

In early childhood education, the demand for responsible and professional service is crucial. Teachers who have a central role in the school are required to fulfill a set of educational standards that include pedagogical, professional, personality, and social norms. These standards indicate a quality threshold of Indonesian teachers. Regulation number 16 year 2007 about Academic Qualification Standards and Teachers' Competences issued by Indonesia's Ministry of Education explicitly governs the expectations for qualifications and competences of teachers of early childhood learning. This regulation also considers teaching skills as one of integral factors in achieving quality education.

As to the importance of teaching skills, it is necessary to organize programs that can help improve these skills. It is said that teachers ' knowledge and skills, as well as their thorough understanding of educating children in accordance with their unique developmental characteristics, can support their optimal growth and development (Semiawan, 2002, p. 25). As a response to enhance teachers' professionalism, article number 26 in Regulation number 19 year 2005 about the National Standards of Education administers the requirements for teachers. Teachers thus are required to have qualifications that include both academic and competency skills. Teachers' competence includes pedagogical, personality, professional, and social abilities. Academic eligibility, on the other hand, is based on specific educational levels.

Teaching skills of early childhood in-service and pre-service teachers are varied. The previous study investigated the use of technology in assessing teaching skills. This study showed that the development of teaching skills could be 
monitored through a technology-based assessment tool (Nurani \& Utami, 2015). The results of this study imply the event of a model related to teaching skills. Development of teaching skills models for early childhood teachers based on effective communication provide a variety of opportunities for teachers in positions and pre-positions in addressing the obstacles that may be related to skills and activities Teach them. Effective communication is believed to support teachers in establishing effective communication with children. By understanding children, teachers can help them improve their optimal achievements. The development of this teaching skills model is necessary to improve the teacher's pedagogical competence and to learn quality as well as to offer an alternative paradigm that switches from conventional paradigms in early childhood education. The development of this model involves early childhood education (PAUD) teachers in Jakarta, educators, experts, and communication experts to get comprehensive results that are not only effective but also workable and not in accordance with the concept of early childhood education in Indonesia..

\section{Method}

The research uses research and development (R\&D) design. Richey and Nelson showed that development research was oriented towards the development of the product that the process thoroughly described and whose final product was evaluated (Richey and Nelson, 1996). In this study, R\&D is used as a method for developing products, i.e. training design. This is done by first exploring the problems faced by prospective PAUD teachers at PAUD teacher training institutes throughout Jakarta province so that the development of effective communication based teaching skills model can be built Theoretically. Van den Akker views the R\&D as a form of formative research, which is research conducted through the cycle process and aims to optimize the quality of product applications in certain situations (Van den Akker, 1999). The results gained from exploring the problem through theoretical and paraxial analysis of the needs assessment were then used as the basis for designing the product. Thus, it can produce a teaching skills model based on effective and moral communication. To adapt to the theory, the R \& D research process follows the cycle pattern, from designing to testing the model design developed using an effective communication approach that will be implemented through practical experiments, discussions, and Consultation. Following this procedure, this research will produce products that are theoretically, methodologically, and empirically.

The first phase of the study is expert analysis of concepts and validations, followed by testing products to see how it works in the learning settings. The Data obtained is used as a basis for designing and revising the model, resulting in a valid model. Class action research was conducted in instructional activities conducted by the teacher (Sugiyono, 2009).

\subsection{The Technique for Data Collection}

In this phase, data is collected using document analysis, interviews, class observations, questionnaires and tests. Document and literature analysis is done to build a concept of effective communication-based teaching skills. This is followed by a focus group discussion with experts to validate the idea. Data on early childhood teacher teaching practices were gathered through document analysis and class observations using grading scales to capture portraits of teacher teaching skills. In addition, interviews were conducted to validate information obtained from observations and questionnaires.

Product development and data collection are done in two steps. The first step is to validate the concept of effective communication-based teaching skills and limited experimental models to get qualitative data that the results used as a basis of consideration to determine whether it is necessary to Revise or improve the model. To collect data, observation and interviews are required. The second step is an extensive experiment model. After improving the design, researchers conducted a wider experiment. The goal is to collect quantitative data derived from trials and qualitative data on the effectiveness of developed models. Subsequently, the model was evaluated through observations, questionnaires, tests, and interviews.

\subsection{Research Participants}

Model development for effective communication-based teaching skills as a form of training for teacher students as prospective teachers focused on developing effective communication-based teaching skills. The goal was a pre-post teacher as a candidate for teachers and teachers in the Department of Early Childhood Education and took the subjects of Curriculum 1 (theory) and Curriculum 2 (practice) at the Department of Early Childhood Education, Faculty of Education, Jakarta State University, Jakarta. 


\subsection{The Technique for Data Analysis}

This research uses quantitative and qualitative data analysis. Quantitative analysis was called to analyse the descriptive score gained from assessing concepts that included scoring scores from experts. This is then followed by qualitative analysis. Quantitative analysis is also performed on any data cycle gained from observing teacher teaching skills. To ensure accountability, data triangulation is done. In this study, researchers triangulated data with resources. Qualitative comparative analysis (QCA) is also conducted to see how teacher teaching skills increased when using models as well as the suitability and application of models for teacher teaching ability and teaching arrangements.

\section{Result and Discussion}

\subsection{Development of Teaching Skills Model Concept Based on Effective Communication}

The results of the research in teachers' effective communication-based teaching skill development are conducting the criterion in indicators of effective communication-based teaching skills. The criterion is divided into eight aspects of teaching skill that determine the effective communication-based teaching skills to be used in early childhood education settings.

Table 1. Indicators Early Childhood Teachers' Effective Communication Based Teaching Skill

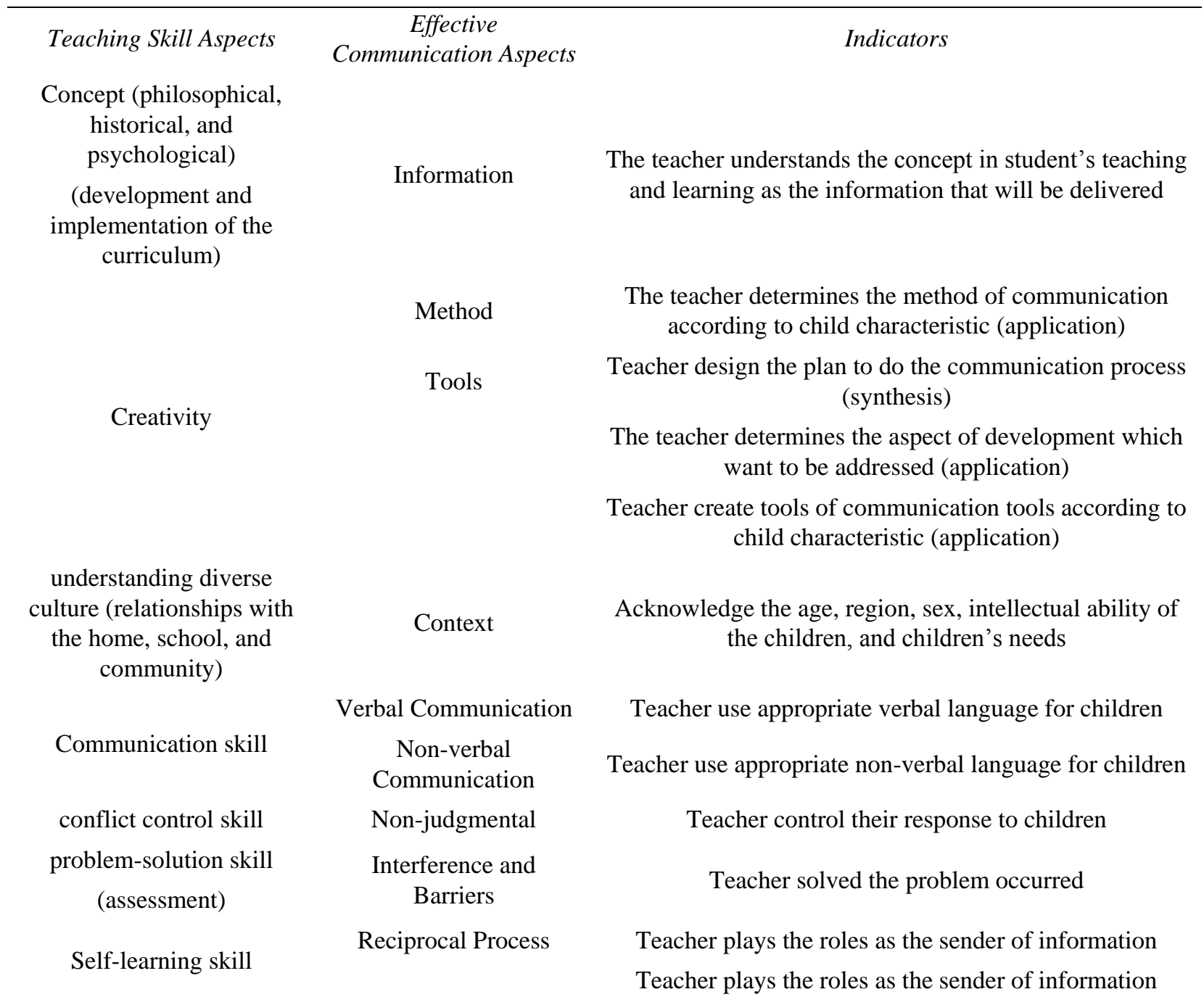

Communication plays an essential role in delivering a message to someone. Likewise in learning activities, communication is necessary for learners to understand the material presented by the teacher. The content will be provided well if the teacher has interesting communication skills and is easily followed by the students. Good communication will also make it easier for teachers to achieve their learning objectives. 
Early childhood education (PAUD) teachers as second educators after parents at home, also need to have good communication skills. Especially in delivering learning materials in early childhood. Not only in conveying the material, but also establishing good communication with the parents. This is what underlies the need for teaching skills owned by an effective communication-based teacher.

This research resulted in a draft of effective communication-based teaching skills, which will be given to students of S1 early childhood education in the lecture. This model Draft will later be developed into a guidebook and module that early childhood education (PAUD) teachers will use in teaching. This Draft teaching skill model has been discussed by conducting expert validation, both from teaching skills experts and communication experts.

\subsection{Expert Validation Result Analysis on Teaching Skill Model Indicators Based on Effective Communication}

The validation is done with the help of 7 expert people, consisting of early childhood education (PAUD) experts, development Research experts, communication experts and teaching skills experts. The validation process is done two times. The results of the validation analysis are then converted to the table of results effectiveness guidelines below.

Table 2. Validation Convention Guidelines

\begin{tabular}{cc}
\hline Presentation of the obtained value $(\%)$ & Criteria \\
\hline $\mathrm{X}>76$ & Very Good \\
$50<\mathrm{X} \leq 75$ & Good \\
$25<\mathrm{X} \leq 50$ & Poor \\
$\mathrm{X} \leq 25$ & Very Poor \\
\hline
\end{tabular}

The results of the validation analysis by experts on the model indicators of effective communication-based teaching skills developed in the table below:

Table 3. Expert validation percentage towards effective communication-based teaching skills model

\begin{tabular}{cccccc}
\hline \multirow{2}{*}{ No } & \multirow{2}{*}{ Aspect Assessment } & \multicolumn{2}{c}{ Phase 1 Validation } & \multicolumn{2}{c}{ Phase 2 Validation } \\
& & Value $(\%)$ & Criteria & Value $(\%)$ & Criteria \\
\hline 1 & Relevance & 62 & Good & 86.11 & Very Good \\
2 & Accuracy & 65 & Good & 100 & Very Good \\
3 & Completeness & 75 & Good & 81.25 & Very Good \\
4 & Systematic & 62.5 & Good & 80 & Very Good \\
5 & Conformity & 70 & Good & 90 & Very Good \\
6 & Manner of presentation & 75 & Good & 100 & Very Good \\
7 & Language & 75 & Good & 87.5 & Very Good \\
& Total & 69.21 & Good & 89.27 & Very Good \\
\hline
\end{tabular}

Validation by experts is done 2 (two) times. From the table of the 1 st expert (first) validation to the communication-based teaching skills model is achieved on the average score of 69.21 and is well-meaning in good category. In the 2nd expert (second) validation process against the effective communication-based teaching skills model, the average value of 89.27 is achieved and is intended in excellent criteria. The Total assessment of each stage of validation, based on relevance indicators, accuracy, completeness, systematic, conformity, presentation, and language. 


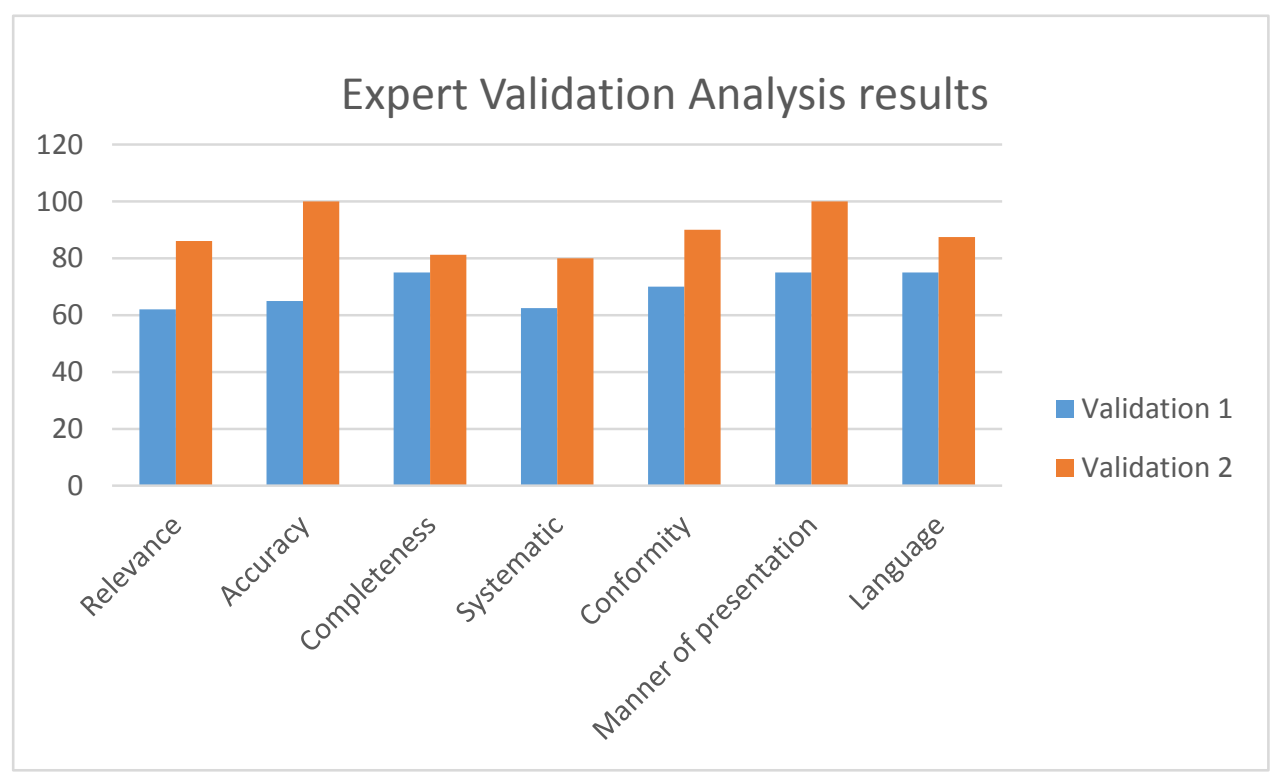

\section{Conclusion}

Figure 1. Comparison Diagram of expert validation results each stage

In implementing the initial assessment to see the teaching skills and forms of communication used by early childhood education (PAUD) teachers, it is apparent that teachers have not used effective communication in the learning activities. This condition that underlies the need for the development of teaching skills (teaching skill) master early childhood education (PAUD) based effective communication (in-service training teacher) which is expected to develop a pedagogic competence of teachers, improve the quality of and changes in the conventional early childhood education (PAUD) paradigm.

A preliminary step conducted by researchers in the development of this effective communication-based teaching skills model is leading the discussion of effective communication concept for early childhood education (PAUD) teachers. It is a reference for researchers in making design of the development model according to the needs and conditions in the field. The next stage after obtaining the analysis of the need to create a design development model, researchers carry out discussion of drafting and formulation of the design of the instrument grid effective communication.

The acquisition of design and grating of effective communication instruments and teaching skills is made essential in the preparation and maturation of effective communication-based teaching skills model. The results of the drafting and maturation of this draft model continued by conducting Focus Group Discussion (FGD) and the validation of experts on the model. Validation concept is done to the idea of teaching skills and also effective communication.

The validation result of the draft model of effective communication-based teaching skills from each expert of the concept will be revised by the researcher on the subsequent research implementation. The lack of consistency of the samples involved in this research resulted in researchers having to conduct several discussions, both on the preparation of the instrument's grid of teaching skills and effective communication. Fore need to implement technological use in maximising effective teaching and communication skills. From the overall application of the research that has been done is the conclusion that with the model of teaching skills development based on effective communication (in-service training teacher) is necessary for the effort to improve the competency of teachers PAUD and also the quality of learning in the service of early childhood education (PAUD) institutions.

\section{Acknowledgements}

This research was supported by the Ministry of Research, Technology and Higher Education.

\section{References}

Adler, R., \& Towne, N. (1978). Looking out/looking in, (2nd ed.). New York: Holt, Rinehart and Winston. https://doi.org/10.1177/105960118100600111

Cochran-Smith, M., \& Lytle, S.L. (1999). Relationships of knowledge and practice: Teacher learning communities. Review of Research in Education, 24, 249-305. https://doi.org/10.3102/0091732X024001249 
Pramling Samuelsson, I., \& S. Sheridan. (2010). A Turning-Point or a Backward Slide: The Challenge Facing the Swedish Preschool Today. Early Years, 30 (3), 219-227. https://doi.org/10.1080/09575146.2010.513328

Richey, R.C., \& Nelson. WA. (1996). Developmental Research. In D.H. Jonassen (ed). Handbook of Research for Educational Communications and Technology, New York: Simon \& Schuster MacMillan.

Semiawan, Conny. R. (2002). Belajar dan Pembelajaran dalam Taraf Usia Dini, Jakarta: PT Ikrar Mandiri Abadi.

Sheridan. S., Williams. P., Sandberg. A., \& Vuorinen, T. (2011). Preschool Teaching in Sweden- A Profession in Change. Educational Research Online) Journal. https://doi.org/10.1080/00131881.2011.625153

Sugiyono. (2009). Metode Penelitian Bisnis (Pendekatan Kuantitatif, Kualitatif, dan R\&D), Bandung: Alfabeta.

Van den Akker. (1999). Principles and Methods od Development Research. In van den Akker, R. Branch, K. Gustafson, N. Nieveen, and T. Plomp (Eds), Design approaches and tools in Education and Training, Dordrecht: Kluwer Academic Publishers. https://doi.org/10.1007/978-94-011-4255-7

Wenglinsky, H. (2002). How Shools Matter: The Link Between Teacher Classroom Practices and Student Academic Performance. Eduaction Policy Analysis Archieve. (Online). https://doi.org/10.14507/epaa.v10n12.2002

Yoon, H., Kim, Y., Lee, K., \& Jeon, J. (2007). A Study on Developing a Key Competence in the Primary/Secondary School Curriculum for the Future of Koreans, KICE report, RRC2007-1.

Yuliani, N., \& Utami, AD. (2015). Implementing ICT in Assessing Student's Teaching Skill. Educational Technology World Conference. 